\title{
Phaeoclavulina decurrens (Gomphales, Basidiomycetes) - the first record for a coral fungus for the Maltese Islands
}

\section{Mifsud, $\mathrm{S}^{1}$}

${ }^{1}$ EcoGozo Directorate, Ministry for Gozo, Victoria, Gozo, Malta.

Mifsud, S. 2019 - Phaeoclavulina decurrens (Gomphales, Basidiomycetes) - the first record of a coral fungus for the Maltese Islands. Microbial Biosystems 4(3), 55-59.

\begin{abstract}
The study about the mycobiota of the island of Gozo within the Maltese archipelago has resulted in the finding of new record of a basidiomycete - Phaeoclavulina decurrens. It is a coral fungus that grows on leaf litter of deciduous trees, where in fact, it was located under Ceratonia siliqua in a maquis community. The record as well the genus is also new for the Maltese Islands. A morphological description supplemented with macro- and micro-photographs are presented together with details about the ecology of this record. A brief taxonomic account of this species and its resemblance with closely related species are discussed.
\end{abstract}

Key words - Central Mediterranean Region, Gozo, Ramaria, subgenus Echinoramaria

\section{Introduction}

The mycobiota of the Maltese islands, an archipelago of five islands with a total surface area of $316 \mathrm{~km}^{2}$, have been studied in staggered periods: at the early $20^{\text {th }}$ century by Saccardo (1912, 1914, 1915) and Sommier and Caruana Gatto (1915); the seventies and eighties by Michael Briffa and Edwin Lanfranco (e.g. Briffa and Lanfranco 1986); and again since the last fifteen years by a few authors. Naturalists and mycologists have based their mycological studies in the few woodlands scattered in mainland Malta, namely from Buskett Woodlands, which is the largest wooded area for Malta. Limited mycological effort have been achieved in Gozo, the second largest island with a surface area of $67 \mathrm{~km}^{2}$. The records of macrofungi from Gozo are only a small fraction compared to those that have been recorded in mainland Malta and the latter are still an unrepresented number of the actual mycobiota occurring on the Maltese Islands. The author commenced mycological investigations in Gozo since the last ten years which resulted in some important contributions not only to this small island but to the national inventory of microfungi e.g. teleomorphic Ascomycota (Cosmospora cf. flavoviridis (Fuckel) Rossman \& Samuels, Morchella galilaea Masaphy \& Clowez, Erysiphe heraclei DC in Mifsud 2017a, b, c), Protozoan fungal analogues (Lycogala confusum Nann.-Bremek ex Ing in Mifsud 2017c) and Basidiomycetes (Terana caerulea (Schrad. ex Lam.) Kuntze and Leucoinocybe lenta (Maire) Singer in Mifsud (2017a). Investigations in Gozo are continuously resulting in interesting findings from species to order level and this account documents another important record from Gozo which is new to the Maltese Islands. 


\section{Materials and Methods}

On the $1^{\text {st }}$ December 2019, a foray was conducted in the gorge-like valley of Mgarr ix-Xini, located at the locality of Xewkija in Gozo. This valley is characterized by vertical or subvertical rocky valley sides up to 20 metres high resulting in a sheltered, shaded and damp environment, providing a habitat for maquis phanaerophytes namely Ceratonia siliqua L., Prunus dulcis L., Crataegus monogyna Jacquin, Ficus carica L. Rhamnus oleioides L. Pistacia lentisus L. and Rubus ulmifolius L. The rock is a sedimentary limestone known as the Lower Coralline Limestone. The valley floor is seldom inundated with water but the layer of soil is damp to wet and it gives rise to a dense maquis of the trees mentioned above. Amongst the specimens of macrofungi and myxomycetes collected, there was a coral fungus (Ramaria s.1.) growing on leaf litter of Ceratonia siliqua about $20 \mathrm{~cm}$ deep, and close to vertical rocky escarpments. Five isolated individuals (fig. 1) were founds within an area of $3 \times 1 \mathrm{~m}$.

Identification was carried out using standard morphological examinations and microscopy methods for macrofungi (Clémençon 2009). An Optica B350 light microscope was used to study the cellular tissue of the specimen stained with $1 \%$ Congo Red. The ornamentation of the spores where visualized under the $\times 100$ (oil immersion) after they were stained by lactic acid Cotton Blue and heated for ten seconds (Peterson 1990). Chemical tests on the surface of the fresh basidiocarp included 10\% KOH; aqueous solution of Ferrous Sulphate and Iodine solution (Meltzer's reagent). Examination of the rhizomorphs, which consisted of a network of rootlets at the base of the basidiocarp was also essential for determination purposes. Small pieces of rhizomorphs about 1 $\mathrm{cm}$ long were transferred in a drop of water on a glass slide and tampered gently to release the crystals that are adhered to their surface. Identification was carried out using the key by Peterson (1990), aided with that of Giachini and Castellano (2011).

\section{Results}

\section{Description of the collection}

Ramaroid fruiting body (Fig. $1 \mathrm{a}, \mathrm{b}$ ) up to $80 \mathrm{~mm}$ high, ochre to buff in colour fading to a white stem, 5-12 mm wide. No colour change on bruising the surface. Branches proliferous and congested, erect, slender $(0.5-3 \mathrm{~mm})$ homogenous in colour, flapped at the uppermost axils ending with slender, short (c. $1 \mathrm{~mm}$ long) horn-like pointed tips that become brown in mature specimens or when drying. Stipe branching from the base and covered by a fine sheet of white mycelia, (sometimes present in the upper secondary branches too). Rhizomorphs abundant, net-like encasing the substrate with numerous stellate crystals on their surface. Scent mildly earth-farinose. Taste acrid somewhat foetid with a slight burning aftertaste. Basidia tetrasporous, cylindricalsubclavate with long, needle-shaped sterigmata up to $5.5 \mu \mathrm{m}$ long and with clamp connections at the base. Spores (Fig 1c) (4.2-) $4.9(-5.5) \times(2.5-) 2.9(-3.2) \mu \mathrm{m}$, Q-factor (1.3-) $1.7(-2.0)$, $[\mathrm{n}=17]$, lachrymoid when mature, covered by large isolated spines or pointed tubercules. Clamp junctions present and rather frequent. Chemical reaction to $10 \% \mathrm{KOH}$ : negative (or just browning slightly); Ferrous Sulphate: dirty dull green reaction; Melzer's Reagent: negative.

\section{Determination}

The ramaroid fruiting body and the echinulate-verrucose ornamentation of the spores place this fungus in the genus Phaeoclavulina (Giachini and Castellano, 2011). The stellate crystals, the $5 \mu \mathrm{m}$ long spores, the thick stem $(>5 \mathrm{~mm})$, the ochre colour which don't bruise and the profusely ramified basidiocarp branching from the base were determinant characters to further identify this species as Phaeoclavulina decurrens (Pers.) J.H. Petersen (Peterson 1990).

\section{Discussion}

Phaeoclavulina decurrens is closely related to P. flaccida (Fr.) Giachini. where it was initially synonymised with, when the genus Phaeoclavulina was erected and consequently the 
species of Ramaria subgenus Echinoramaria were recombined within (Giachini and Castellano, 2011). Nevertheless, Læssøe and Peterson (2018) have advocated for the distinctness of $R$. decurrens and provided its combination in Phaeoclavulina. According to Petersen (1990), the difference between $P$. flaccida and $P$. decurrens is that the former grows on conifer needles, forms a smaller fruiting body $(5 \times 3 \mathrm{~cm})$ and produces larger spores $(7.0-9.5 \mu \mathrm{m}$ long $)$ compared to the saprobic growth on leaf litter of broad-leaf trees of $P$. decurrens which give rise to larger fruiting bodies up to $14 \mathrm{~cm}$ long and possess spores measuring 5.2-6.7 $\mu \mathrm{m}$ long. Another closely related species is $P$. roellinii Schild. a rather well known species in Europe but with a more northern distribution (Asturnatura 2019). P. roellinii is also a smaller species (up to $3.5 \mathrm{~cm}$ long) with slightly larger spores $(6.5-8.0 \mu \mathrm{m}$ long), lower branches only up to $2 \mathrm{~mm}$ thick and grows amongst mosses and lichens (Peterson 1990, Kř́ž et al. 2019, Giachini et al. 2019).

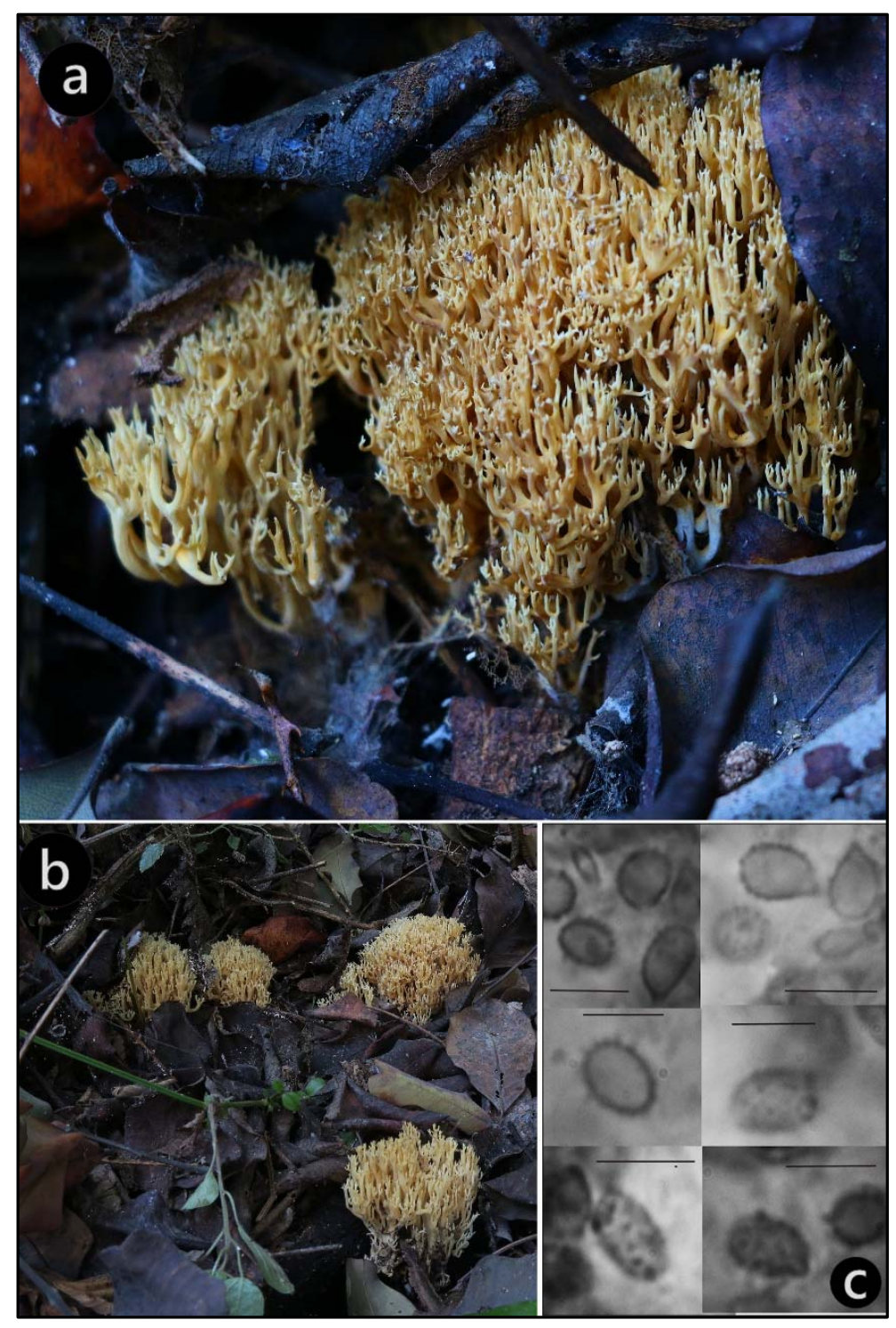

Fig. 1 - Phaeoclavulina decurrens (Pers.) J.H. Petersen: a. Fruiting body in situ; $b$. four of the five specimens growing on leaf litter of Ceratonia siliqua L. at Mgarr ix-Xini, Xewkija, Gozo (1-Dec2019); c. Mature spores (c. 5 um long) with a lachrymoid outline, oblique and distinct apiculum and isolated verrucose-echinate ornamentation. - Bars $=5 \mu \mathrm{m}$. 
The record of $P$. decurrens in Malta is interesting because it is the first record of Phaeoclavulina from the Maltese Islands and in the Mediterranean region where the southernmost station is from the province of Salamanca in northwest Spain according to Asturnatura (2019). P. decurrens is apparently neither reported in the checklist of Sicilian Fungi (Venturella 1991) or in Italy (Amint 2019). However, Braghi (2016) have reported a ramarioid specimen growing on leaf litter of Quercus sp. from Lombardy, Italy (October, 2006). This is macro-morphologically very similar to the Maltese collection and similarly, it has verrucose spores which also measuring 4.9 $-6.0 \mu \mathrm{m}$ long. This population was posted under the name Ramaria flaccida var. crispula (Fr.) Schild, (Braghi 2016) but instead, it might correspond to P. decurrens.

Being an attractive or peculiar fungus resembling coral, and hence subjective to be collected, combined with its presumed rare occurrence in Malta, it is suggested that this species is protected by national law and included in the national Redlist. A revision of the collections of $P$. decurrens, $P$. moellerii and $P$. flaccida s.l. is strongly suggested since of their close morphological relationship and possibly these species have been confused in the past.

\section{Conflict of Interest}

The author does not have any conflicts of interest.

\section{Acknowledgement}

This research is supported by EcoGozo Directorate, Ministry for Gozo as part of its programme to promote and research biodiversity and raising awareness for its appreciation and protection.

\section{References}

AMINT 2019 - Indice delle schede https://funghi.funghiitaliani.it/ (Accessed 15 Dec 2019).

Asturnatura 2019 - Ramaria decurrens (Pers.) R. H. Petersen.

https://www.asturnatura.com/especie/ramaria-decurrens.html (Accessed 15 Dec 2019).

Biraghi M. 2016 - Archivo Micologico: Ramaria flaccida. https://www.funghiitaliani.it/topic/33536-ramaria-flaccida/ (Accessed 15 Dec 2019).

Briffa M, Lanfranco E. 1986 - The Macrofungi of the Maltese Islands: Additions and notes. The Central Mediterranean Naturalist 1(4): 69-79.

Clémençon H. 2009 - Methods for Working with Macrofungi. Laboratory Cultivation and Preparation of Larger Fungi for Light Microscopy. IHW-Verlag.

Giachini AJ, Castellano MA. 2011 - A new taxonomic classification for species in Gomphus sensu lato. Mycotaxon 115: 183-201. DOI: https://doi.org/10.5248/115.183

Giachini A, Castellano MA, Cazares E. 2019 - Systematics of the Gomphales: The Genus Phaeoclavulina Brinkmann. Mycotaxon (in press).

Kříž M, Jindřich O, Kolařík M. 2019 - Contribution to the knowledge of mycobiota of Central European dry grasslands: Phaeoclavulina clavarioides and Phaeoclavulina roellinii (Gomphales). Czech Mycology 71(2): 137-150

Læssøe T. and Petersen JH. (2018). Nomenclatural novelties. Index Fungorum 369. http://www.indexfungorum.org/Publications/Index\%20Fungorum\%20no.369.pdf (Accessed 13 Dec 2019).

Mifsud S. 2017a - Contribution to the Mycobiota and Myxogastria of the Maltese Islands Part 1 (2014-2016). Micologia e Vegetazione Mediterranea. 32 (1): 3-58. 
Mifsud S. 2017b - EcoGozo discovers completely new species of fungi from Gozo. Gozo News (14-Jun-2017). https://gozo.news/67444/ecogozo-discovers-completely-new-species-offungi-from-gozo/ (accessed 14 Dec 2019).

Mifsud S. 2017c. - Additions of mycobiota and myxomycetes of the Maltese Islands. Bulletin of the Entomological Society of Malta, 9, 99.

Petersen JH. 1990 - Key to the species of Ramaria known from Fennoscandia. University of Aarhus, Institute of systematic Botany.

https://www.mycokey.com/MycokeyDK/DKkeysPDFs/RamariaKeyPrint.pdf (accessed 2 Dec 2019).

Saccardo PA. 1912 - Fungi ex Insula Melita (Malta), lecti a Doct. Alf. Caruana Gatto et Doct. Giov. Borg. Bullettino della Società Botanica Italiana.

Saccardo PA. 1914 - Fungi ex Insula Melita (Malta) lecti a Doct. A. Caruana-Gatto et Doct. G. Borg annis MCMXIII, serie II. Nuovo Giornale Botanico Italiano.

Saccardo PA. 1915 - Fungi ex Insula Melita (Malta) lecti a Doct. A. Caruana-Gatto et Doct. G. Borg annis MCMXIII et MCMXIV, serie III. Nuovo Giornale Botanico Italiano.

Sommier S, Caruana Gatto A. 1915 - Flora melitensis nova. Firenze.

Venturella G. 1991 - Checklist of Sicilian Fungi. Bocconea 2:1-221. 